\title{
STRATEGY TO DEVELOP CITY BRANDING OF CIREBON CITY IN WEST JAVA
}

\author{
Nugroho B. SUKAMDANI ${ }^{1}$, T. Titi WIDANINGSIH ${ }^{*}$, Fit YANUAR ${ }^{3}$ \\ ${ }^{1,2}$ Sahid University Postgraduate School Jakarta \\ ${ }^{3}$ Faculty of Communication, Sahid University Jakarta \\ *titi_widaningsih@usahid.ac.id
}

\begin{abstract}
City branding is a means to achieve a competitive advantage to increase investment, tourism, and community development by strengthening local identity and citizens. City branding as a medium and message in marketing the city by using specific symbols and logos. The purpose of city branding is to build a city identity and increase the number of tourist visits. As an effort to build tourism in the city of Cirebon, it launched the City Branding tagline "The Gate of Secret". The city branding strategy was chosen by the Cirebon City government as an effort to focus the tourism development program. Tourism is an important sector in the development of Cirebon City. Tourism is the driving force of economic activity and the locomotive of Cirebon city development. Through the city strategy, it is hoped that there will be an increase in the number of tourist visits to the city of Cirebon. However, city branding has not been able to increase the number of tourists in the city of Cirebon. In 2020, Cirebon city tourists only reached $40.5 \%$ of the target of 2.2 million tourists. Cirebon city branding has not been able to increase the number of tourist visits. The failure of the branding is because the Cirebon city government is still trapped in artificial activities. Where branding is just making a tagline and launching it. The tagline "The Gate of Secret" as a brand has not been integrated with the image of the city, tourist attractions, infrastructure, and society in the marketing strategy. The city branding strategy process has not been carried out by the Cirebon City government in developing city branding. To achieve the success of city branding, the Cirebon city government needs to do marketing. The presentation of tourism elements consists of an image, attraction, infrastructure, and people. These tourism elements must be integrated with city design, architecture, and spatial planning that form city branding. The city branding strategy is carried out by identifying what is owned and used as branding, setting city branding goals, communicating \& interacting with various stakeholders with the city of Cirebon, and finally implementing which ensures all forms of communication from one city can be integrated.
\end{abstract}

Keywords: Strategy, Development, City Branding, Cirebon

\section{BACKGROUND}

Tourism development aims to increase the prosperity and welfare of the people by following per under Law No. 10 of 2009 concerning Tourism. The success of tourism development can increase local revenue and accelerate economic growth. Various regions in Indonesia are trying to develop tourism and differentiate their cities from other cities. Local governments are trying to build their cities so that they are in demand by both domestic and foreign tourists. The increasing number of tourists will increase regional income so that it can turn the wheels of the economy and lead to community welfare.

The local government of Cirebon City encourages the development of the city as a leading cultural tourism destination in West Java. One of the efforts made is to create a city branding. City branding is a means to achieve a competitive advantage to increase investment and tourism, community development, strengthen local identity and community identity with their city and mobilize social activities (Anholt Simon, 2007).

City branding is a city marketing concept using specific symbols and logos to build a city identity and increasing the number of tourist visits. The city of Cirebon once used the tagline "the grate of secret" in 2010, as a lighter for the public to be more curious to know about the city of Cirebon. (Dody Triguna, 2019). As an effort to develop Cirebon city tourism in 2019, the City Branding tagline "The Gate of Secret" was re-launched. The city branding strategy is carried out as an effort for the Cirebon City government to focus on tourism development programs. Tourism is the most important sector in the development of Cirebon City because tourism is the driving force of economic activity and the locomotive of development (http://cirebonkota.go.id).

\section{Problems}

The city branding of Cirebon city with the tagline "The Gate of Secret" was formulated and used in 2010 as an effort to ignite for outsiders to be curious about Cirebon city (Dody Triguna, 2019). The tagline that was formulated in 2010 has not yet been implemented into various tourism policies and activities in the city of Cirebon.

In 2019, the tagline "The Gate of Secret" was reinitiated and designated as the city branding tagline for the city of Cirebon through the Decree of the Mayor of Cirebon No. 430/Kep.-DKOKP/2019 concerning the Determination of Branding in the City of Cirebon. The Cirebon City Government released the city branding tagline at the Cirebon X-pose 2019 event in the 2019 Cirebon City Festival series of events.

The target of tourist visits to Cirebon City is by following per under the Regional Medium-Term Development Plan for the city of Cirebon in 2019 as many as 2.1 million and 2020 as many as 2.2 million. In 2019, the number of tourist visits to the city of Cirebon was 978,064 people. Tourist visits during 2020 only reached $40.5 \%$ of the target. (Ceremaitoday.com, Cirebon). Cirebon city branding has not been able to increase the number of tourist visits. This is because the Cirebon City government has not developed city branding optimally. City branding 
doesn't just define taglines and launches. City branding must be marketed with a marketing strategy by integrating the brand with the image of the city, tourist attractions, infrastructure, and society in the marketing strategy. The process of branding strategy must be carried out properly starting from determining identity, goals, communicating, and integrating all forms of communication. The Cirebon city government has carried out a marketing strategy and the process of developing city branding but it has not been maximized.

\section{Cirebon City Branding Development Strategy}

A brand is a proper and decent label to describe an object being marketed (Shimp, 2010:7). A brand is a product or service that adds dimensions that differentiate it from other products or services designed to satisfy consumer needs (Kotler \& Keller, 2013, p. 332). The essence of the brand is a promise, the promise must be relevant to the quality and entity being offered.

City branding as a city marketing effort uses specific symbols or logos intending to build a City Indentity and increasing the number of tourist visits. The city of Cirebon has established a city branding with the tagline "The Gate Of Secret". The success of city branding can be seen from the city image, which is formed based on tertiary communication (word of mouth). City government primary communication and campaigns through Public Relations and advertising as secondary communication.

City branding adapted from corporate branding is a perception in the minds of consumers, be it tourists, investors, and the public, related to the credibility of the city that affects the interest in visiting. City branding is a perception in the minds of consumers based on the visualization of a place that is realized through goals, communication, values, stakeholder culture, and overall city design. (Zenker \& Braun, 2011, Yananda \& Salamah, 2014).

The marketing strategy in urban development needs to be carried out by the local government of Cirebon city in marketing and encouraging the city of Cirebon to attract more tourists, entrepreneurs, investors, and other stakeholders. Activities from the city branding strategy of the city of Cirebon in increasing tourist visits by carrying out marketing strategies by communicating tourism elements include:

1) Image Marketing: To support tourism, the Cirebon City government has carried out branding with the tagline "The Gate of Secret". The meaning of the tagline is a secret gate, which implies art, culture, customs to reliefs and buildings that have a very deep philosophical meaning. with the tagline "The Gate of Secrets". is expected to make the public curious and want to know the secrets that exist in the city of Cirebon. so that it will generate public interest to visit and explore the city of Cirebon.

2) Attraction Marketing: Cirebon City has a number of tourist attractions that can be used as capital in a city branding strategy, thus making Cirebon City a destination of choice for tourists. Historical tourist attractions and centers of civilization such as Goa Sunjarangi, Kaprabonan, Petilasan Sunan Kalijaga, Masjid Merah Panjunan, Kelenteng Welas Asih, Kelenteng Talang, Mesjid Agung Sang Cipta Rasa, Keraton Kacirebonan, Keraton Kanoman, Keraton Kasepuhan, Patilasan Pangeran Drajat, Dalem Agung Pakungwati. The city of Cirebon has various types of foods that can be used as culinary tourism developments such as Empal Gentong, Nasi Jamblang, Nasi Bogana, Sinta Manisan, Tahu Gejrot, Nasi Lengko, Docang. Cultural tours such as Singa Barong Upacara Panjang Jimat, Tari Topeng, Sintren, Tarling, Gembyung. Shopping tours: Pasar Rakyat Cirebon, kampung batik Trusmi. The city of Cirebon also organizes tourism activities in the form of Cirebon Travel Mart and launches Cirebon Tourism on Bus (Citros). The local government of the city of Cirebon also held a City Festival consisting of Cirebon Expose and Cirebon Creative Fashion Carnival.

3) Infrastructure Marketing: Cirebon City is a strategic city located on the north coast of Java bordering West Java and Central Java. Its strategic location on the north coast route provides easy access for tourists from Jakarta, Bandung, and other cities in Central Java. Accommodation facilities, transportation, and supporting factors are quite adequate. Starting from land transportation with dual rail lines, Cipali toll road, air transportation modes with Kertajati International airport. Star hotels and inns as well as other facilities such as shopping centers, health facilities, finance, and good and adequate information technology. Infrastructure as a supporter of the attractiveness of the environment and business environment can attract tourists to visit Cirebon city.

4) People Marketing: Society is a factor that supports the success of city branding. The people of Cirebon City are friendly and religious people who are known as the city of students. The city of Cirebon has competent human resources seen from the number of small and medium entrepreneurial activities. The people of Cirebon City have a diversity of tribes, ethnicities, cultures, and religions. Harmonious Living Together in Diversity illustrates the journey of life for the people of the city of Cirebon. This makes the city of Cirebon a safe, peaceful, and comfortable city. The city of Cirebon also has Sultan Sepuh XIV, Pangeran Raja Adipati Arif Natadiningrat SE, as a figure who is highly respected by the community. Image, attraction, infrastructure, and people marketed are one unit. These elements must be integrated with city design, architecture, and spatial planning that make up city branding. The Cirebon city government has not integrated various elements of tourism in carrying out marketing strategies. The success of city branding can be seen from the city 
image that is formed, which affects people's choices to travel to the city of Cirebon. The branding of a city is often trapped only in artificial activities. Just creating a brand but not integrating the brand with the city's image, services. and existing infrastructure and organization. City branding is used by various cities in the world to improve or change the image of the city by highlighting the advantages and uniqueness of the area. (Murfiany, 2010). The steps involved in the city branding strategy process (Andrea Insch, 2013). Steps for city branding that should be taken by the Cirebon city government.

5) Identity. Cirebon city tagline "The Gate of Secret" is the result of the process of identifying the assets, attributes, and identity of the city of Cirebon which is used as the basis for building city branding (Figure 1). City branding aims to attract tourists and make Cirebon City a preferred tourist destination. The identification that is used as the basis for building the city branding of Cirebon City is (1) the history and center of Islamic civilization in the form of the Kasepuhan Palace, a legacy of Sunan Gunung Jati which is well preserved and beautiful. Sunyaragi Cave. (2) Cirebon arts in the form of Mask Dance, Sintren, Tarling, Gembyung, Cirebonan Drama, and glass painting. (3) Cirebon's well-known culinary riches, for example, Tahu Gejrot, Jamblang rice, sego Lengko, Empal Genthong, big crackers, Mlarat chips. (4) Cirebon people's market and Trusmi batik with a batik pattern in the form of a cloud image known as the mega cloudy motif.

6) Objective. The main goal of building a strong city branding is to encourage the growth of the tourism sector. Tourism is one of the drivers of economic growth. The tourism sector must be built to accelerate economic growth by carrying out city branding. City branding as a strategy to introduce the tourism potential of Cirebon city. Tourism assets in the form of uniqueness and diversity of natural, cultural wealth must be managed and developed marketed so that they become attractive tourist destinations. The success of the development of the tourism sector can accelerate economic growth through contribution to Regional Original Income. The tourism sector in addition to ensuring the preservation of nature, culture also provides jobs for the community to improve the welfare of the community. city branding aims as a competitive means to achieve excellence to increase investment and tourism, community development, strengthen local identity and community identification with their city and mobilize all social activities to avoid division. With the similarity between the government's goals and people's expectations, namely improving the economy and community welfare, this will be a good long- term effect from the implementation of the city branding strategy. Where the welfare of the community increases and the city of Cirebon will be better known and visited by tourists and investors.

7) Communication. The Cirebon City Government has not carried out an integrated communication strategy with the tourism industry players. Communication media has not been used optimally either social media, mass media, and other promotional media. The Cirebon city government has not communicated the tagline "The Gate of Secret" massively with various media and involving various tourism industry players. Besides being introduced to the wider community, the people of Cirebon City need to strengthen their tagline awareness. So that the people of Cirebon City feel close and have a tagline like people love their city. The people ofCirebon city as the main target of tagline socialization are an integrated part of a brand. The residents of the city of Cirebon serve as brand ambassadors and help spread information about their city by word of mouth. The word of mouth communication strategy is one of the most effective communication strategies at a very low cost. The key to the success of Word of Mouth is a product that can provide a pleasant experience for consumers, so positive recommendations will continue to flow and even cannot be controlled by the product owner (Hasan, 2010: 285). The implementation of branding requires a balance between city brands and community support (Braun, Kavaratzis, Zanker, 2010). The product in the form of the city branding tagline "The Gate of Secret" represents the attractions,

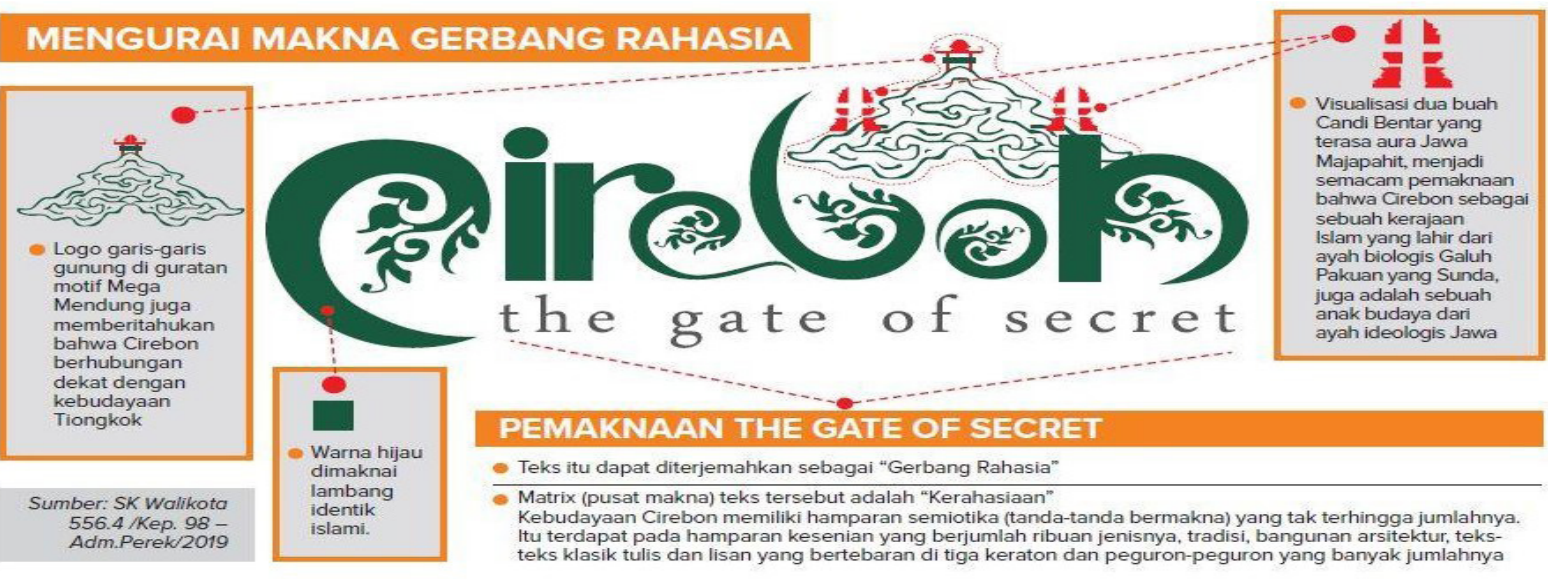

Figure 1. Tagline The Gate Of Secret (Radar Cirebon.com 9 Maret 2019) 
amenities and accessibility offered to tourists, which must be able to provide an interesting experience for the community. Interesting experiences will make people give positive recommendations to the city of Cirebon. This will have an impact on new tourist visits or repeat visits by old tourists. The next communication strategy can be done using a public relations strategy. The local government of the city of Cirebon through the communication \& informatics office as well as local government public relations and the public relations of the tourism office must be able to work together to introduce "The Gate of Secret", for example by creating a website. An easily accessible website with an attractive and interactive display to get feedback and capture public opinion on the branding of the city of Cirebon. Conducting digital campaigns through social media interestingly and creatively. The social media used by the Cirebon city government is the Website:https://dkokp.cirebonkota.go.id/. Youtube: Disporbudpar Cirebon \& Cerbon Culture, Instagram: @ disporbudparkotacirebon, Facebook: Cirebon Tourism, Twitter : @dkokp_Cirebon. The online media used by the tourism office of the city of Cirebon has not seen any branding efforts (figure 2). In conducting the campaign, you can use influencers. The selection of influencers must be appropriate, by following per under the product to be introduced, namely the Cirebon city tagline. Cooperation needs to be done by establishing communication with travel bloggers, video bloggers, social media influencers to create creative content related to the tagline "The Gate of Secret". Social Media is more effective, easier, and less expensive. Everyone can participate in the process of implementing City Branding. Steps that can be taken to support the city branding campaign are media relations. Inviting local, national, and global media. Media selection must be adjusted to the product or tagline to be introduced. Mass media is the right means to publish the city of Cirebon with the tagline "The Gate of Secret".
Communication can be done by creating a special interactive booth "The Gate of Secret" in strategic places such as stations, airports, terminals, malls. Utilize various other promotional media such as leaflets, booklets, billboards. Another strategic step was taken by holding an event related to "The Gate of Secret". These campaigns and events will be more successful and get the attention of outside audiences if they get publications from mass media such as $\mathrm{TV}$, radio, newspapers, and magazines. Various communication strategies need to be carried out. so that the tagline "The Gate of Secret" is always in the minds of the people. Thus increasing the number of tourist visits to the city of Cirebon. The Cirebon city government has used digital media in its city branding campaign. but the use of digital media has not been maximized. The public relations strategy has also not been carried out properly. Events for city branding have been carried out well, but publications from the mass media have not been maximized. Media relations need to be improved by the Cirebon city government.

8) Coherence. The Cirebon city government has not carried out an integrated communication program. All forms of communication programs of a city must be integrated, consistent, and convey the same message. The Cirebon City Government must involve the community, especially tourism business actors to always use the tagline "The Gate of Secret". The process of communication and interaction with various parties with an interest in a city. The use of branding in every promotional product, both hotels, and travel agents must use the Cirebon city branding "The Gate of Secret". All tourism business actors work together to brand the city with one tag line, namely "The Gate of Secret". Tourism industry players such as hotels, shopping centers, tourist attractions in the city of Cirebon have not all been involved in promoting city branding through such as shopping bags, food packaging, souvenirs, and others. The Cirebon

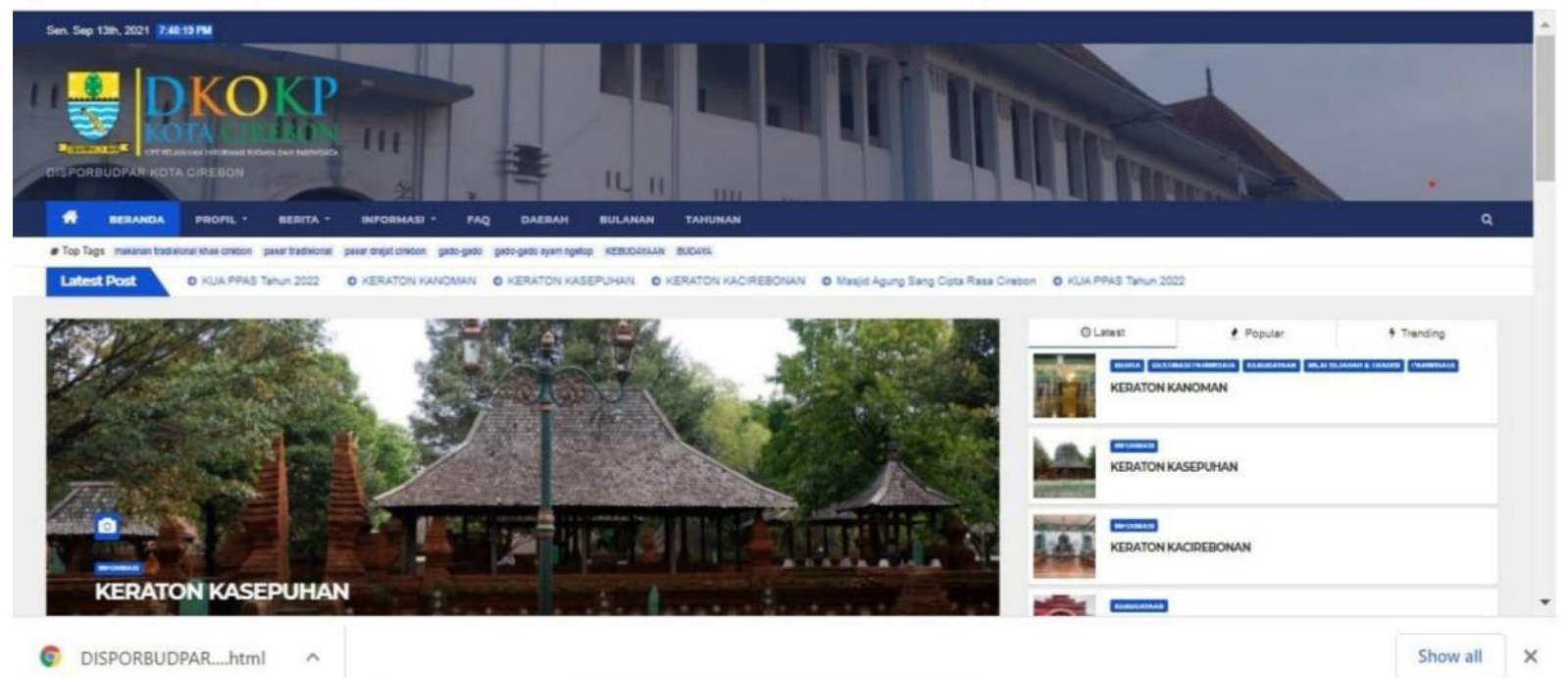

Figure 2: Website: https://dkokp.cirebonkota.go.id/ 
City Government must communicate with various interested parties, including hotels, travel agents, and tourism business actors. All stakeholders can formulate breakthroughs for the development of tourism in the city of Cirebon, especially in realizing the vision of the city of Cirebon to realize the visit of two million tourists every year to the city of Cirebon. The city branding program for the city of Cirebon must support this vision.

\section{CONCLUSION}

Tourism as a driver of economic activity and development of Cirebon city. Cirebon city government launched the city branding of Cirebon city as a lever to increase tourists visits. The City branding strategy carried out by the Cirebon city government has not been able to increase the number of tourist visits. In 2020, tourist visits are only $40.5 \%$ of the target. failure in building city branding because the Cirebon City Government has not integrated the brand with the city's image, tourist attractions, infrastructure, and society in the marketing strategy.

The city marketing strategy that should be carried out by the Cirebon city government is by marketing (1) The image of the city of Cirebon with the arts, culture, customs of Cirebon which has a very deep philosophical meaning. with the tagline "The Gate of Secrets". (2) Historical tourist attractions and centers of civilization, culinary, cultural tourism, shopping tours. (3) Cirebon City infrastructure with easy access and adequate tourist facilities. (4) The residents of Cirebon City are friendly and religious people with ethnic, ethnic, cultural, and religious diversity. Harmonious Living Together in Diversity makes the city of Cirebon a safe, peaceful and comfortable city. Image, attraction, infrastructure, and people marketed are one unit. These elements must be integrated with city design, architecture, and spatial planning that make up city branding.

The Cirebon city government has not consistently carried out the Steps in the city branding strategy. (1) identification of what is owned and used as a branding of the city of Cirebon such as history and the center of civilization, arts, culture, culinary wealth, shopping centers have been carried out. (2) The purpose of city branding is to encourage the growth of the tourism sector. City branding has been established as a strategy to introduce the tourism potential of the city of Cirebon. (3) Communication and interaction of various interested parties with the city of Cirebon. The Cirebon City Government has not carried out an integrated communication strategy with the tourism industry players. (4) Implementation that ensures all forms of the grate of secret communication are integrated. The communication program has not been integrated, consistent and conveys the same message.
The community, especially the tourism business actors, have not been involved in the use of the tagline "The Gate of Secret".

\section{REFERENCES}

Anholt, Simon. (2007). Competitive Identity: The New Brand Management Nations, Cities, and Regions.

Palgrave Macmillan, USA.

Braun, E., Kavaratzis, M., \& Zenker, S. (2010). "My City-My Brand: The Role of Residents in Place Branding".

Journal of Place Management and Development, 6(1), $1-13$.

Dody Triguno. (2019) Menilik City Branding Baru Kota Cirebon, The Gate of Secret. Bisnis Indonesia, Writing Contest.

Hasan, Ali. (2010). Marketing Dari Mulut Ke Mulut. Media Pressindo, Yogyakarta

Insch, Andrea. (2013). "Elements of the City Branding Process to Support Global City Status” Proceedings of International City Branding Symposium.

Kavaratzis, M. (2004). "From city marketing to city branding: Towards a theoretical framework for developing city brands". Place Branding. 1(1), 5873. https://doi.org/10.1057/palgrave.pb.5990005

Kotler, Philip \& Keller, Kevin Lane. (2013). Marketing Management (14 $14^{\text {th }}$ Edition). Pearson Education, England.

Murfianti, Fitri. (2010). "Membangun City Branding Melalui Solo Batik Carnival”. Jurnal, Acintya, 2(1). https://doi.org/10.33153/acy.v2i1.101

Smart City. (2019). "Pemkot Cirebon Launching Branding Kota Cirebon The Gate of Secret". http:// cirebonkota.go.id, March 3, 2019

Shimp, T.A. (2010). Advertising, Promotion, \& other aspects of Integrated Marketing Communication, $8^{\text {th }}$ Edition. Cengage Learning, South-Western.

Undang-Undang Republik Indonesia, Nomor 10 tahun 2009 tentang Kepariwisataan pada Bab I Pasal 1) Yananda, M.Rahmat, dan Salamah, Ummi. (2014), Branding Tempat: Membangun Kota, Kabupaten, dan Provinsi Berbasis Identitas. Makna Informasi, Jakarta.

Zenker, S. and E. Braun. (2017). “ Questioning a 'one size fits all' city brand: Developing a branded house strategy for place brand management". Journal of Place Management and Development, 10: 270287.

Zenker, S., E. Braun and S. Peterson. (2017). "Branding the destination versus the place: The effects of brand complexity and identification for residents and visitors". Tourism Management, 58: 15-27. 